\title{
Personality Traits in Relation to Academic Performance of Accountancy, Business and Management Strand Students
}

\author{
GYLLEVI PRYLLE F. BONGATO \\ gpfbongato@universityofbohol.edu.ph \\ https://orcid.org/0000-0002-3552-7510 \\ EMMA S. RULONA \\ esrulona@universityofbohol.edu.ph \\ https://orcid.org/0000-0001-5310-8419
}

\begin{abstract}
This study seeks to determine the relationship of personality traits under the big five dimensions of personality theory and academic performance of the students. This study intends to benefit not only to the respondents but also to the teachers, institution, guidance counselors and parents. There were 224 accountancy, business, and management strand students of University of Bohol-Senior High School who were the respondents. Findings of the study revealed that under the big five dimensions of personality theory, the students obtained high in the following dimensions, namely, openness, extraversion, neuroticism, and agreeableness while very high in conscientiousness. The researchers concluded that there is no relationship between the personality traits and academic performance of the students.
\end{abstract}

Keywords: Personality Traits, Academic Performance, descriptive, Philippines 


\section{INTRODUCTION}

In today's world, some level of education is essential for individuals in most countries. Due to population development and the multiplication of compulsory education, UNESCO has determined that in the following 30 years, a bigger number of individuals will get formal training than in any earlier time of human history. Truth be told, lack of education and the level of populations with no schooling have effectively diminished, from $36 \%$ in 1960 to $25 \%$ in 2000 (Lumen, 2015).

Personality characteristics replicate people's attribute patterns of thoughts, feelings, and behaviors. Personality traits suggest consistency and stability, and that someone who scores excessively on a precise trait like extraversion is anticipated to be sociable in distinct situations over time (Diener, \& Lucas, 2018). Personality is said to be one of the factors that affect academic performance either positively or negatively.

Personality trait is important in predicting success in various domains. It has been recognized as a determining factor on how people learn. The Big Five Dimensions of personality theory is one of the prominent theories in contemporary psychology that defines the personalities in five categories namely; Openness to Experience, Conscientiousness, Extraversion, Agreeableness, and Neuroticism (Kumari, 2014). This dimension summarizes the traits that mark careful, responsible and dependable people in contrast to people who are lazy and lack of self-discipline.

Academic performance is the result of education which is an extent to which a student or teacher has achieved their educational goals. Academic performance is usually measured by examinations or continuous assessment but there is no general agreement on how it is best tested or which aspects are most important either procedural knowledge or declarative knowledge. Procedural knowledge is based on skills while declarative knowledge is based on facts (Ward \& Ward, 1996).

The Department of Education in the Philippines implemented a new curriculum that started last school year 2012-2013 named it $\mathrm{K}$ to 12 Curriculum. $\mathrm{K}$ to 12 stands for kindergarten plus twelve years of elementary and secondary education. This educational system is widely adopted around the world. According to the article Enhanced $\mathrm{K}$ to 12 Basic Education Program (2010), $\mathrm{K}$ to 12 is an effective cure to the deteriorating quality of the Philippine education system.

The University of Bohol is one of the schools in Tagbilaran City that follows the $\mathrm{K}$ to 12 Curriculum which has Junior High and Senior High 
offerings. Under the Senior High School is the Grades 11 and 12. Its Senior High has four strands, namely; General Academic Strand (GAS), Accountancy, Business and Management (ABM), Science, Technology, Engineering and Mathematics (STEM), and lastly, the Humanities and Social Sciences (HUMSS).

The University of Bohol intends to optimize the holistic development of every student in its care. With this premise, the researchers became interested in looking into the significant relationship between the personality trait and academic performance of the Grade 12 Accountancy, Business and Management students of University of Bohol Senior High School. The researchers planned to conduct the study to all Senior High School Students but agreed to have it one on one only alphabetically starting with the ABM strand. The main purpose of this study is to determine if personality traits and academic performance have relationships with each other.

Ackerman (2017) in his book Positive Psychology said that the historical backdrop of personality research will be generally partitioned into seven periods, portrayed by totally unique winning hypotheses and hidden theories. The five components came out of many years of identity examination, developing from the establishments of Catell's sixteen factors and changing into the preeminent acknowledged model of identity up until this point. This model has been converted into numerous dialects and connected in many societies, prompting an investigation that not exclusively affirms its legitimacy on a worldwide dimension. Sea is the most wellknown mental aide of huge five characteristics. These five characteristics are receptiveness, principles, extroversion, suitability, and neuroticism. Scruples is a property that might be portrayed as the propensity to control driving forces and act in socially worthy ways that encourage purposive conduct. People in this quality outperform in their capacity satisfaction, work among the standards, mastermind and compose successfully.

Since 1990, various studies utilized instruments that assess personality traits at the Five-Factor Model (FFM) level as classification of individual scales basing from personality inventories. Another distinguishing characteristic is the utilization of meta-analytic methods in summarizing quantitative results across several studies. The authors captured 15 metaanalytic studies of personality-performance relationships. The results of those studies led to more optimistic conclusions helped increase the understanding of personality-performance relationships. It appeared that the analysis showed that some aspects of personality are meaningfully 
related to performance (Barrick, Mount \& Judge, 2008).

Psychologists widely studied personality as a separate discipline which is Psychology of Personality. Such discipline is concerned with the analysis of human nature and theories surrounded by five root ideas of personality, such as motivation, unconscious, self, development, and maturity (Hogan, 1998).

According to Ongore (2014) in his study entitled "A Study of Relationship between Personality Traits and Job Engagement," this study wants to determine the connection between identity characteristics and employment commitment of the college faculty. The gathering of relevant information transpired from 118 workforces. The results of the study showed a significant relationship between personality traits and job engagement. Variables on Extraversion, Agreeableness, Conscientiousness, and Openness to Experience were directly related. However, Neuroticism was inversely related to Physical, Emotional, and Cognitive Engagement. Results further revealed that Openness to Experience was a significant predictor to Physical, Emotional, and Cognitive Engagement. Furthermore, Agreeableness was a predictor to Emotional and Cognitive Engagement. Job Engagement as a higher-order factor was related to big five factors. Results of this study suggested that the Five-Factor Model is useful for examining the dispositional source of job engagement.

According to Boyle (2010) in his study entitled "Current Research in Personality Traits and Individual Difference," identity qualities have been a focal piece of the investigation of identity for a long time or more, from early examinations by psychologists to the later studies by Cattell and Eysenck, and their partners. The more significant part of the exploration has utilized information from self-report inventories, and rating scales and these have presented issues, for example, reaction bending, that has turned into a focal point of further research. A survey of the historical backdrop of identity qualities, the ongoing endeavor to characterize and restrain identity structure to the "Big Five," and the impact of these and related characteristics on conduct is given in this part, which additionally subtleties the hypothetical accentuations related with the different methodologies, particularly in the present century.

The study of Conard (2006) investigated the incremental validity for predicting academic criteria, such as GPA and course performance using the Big Five personality traits, while controlling the academic ability (SAT). Results showed that Conscientiousness incrementally predicted each 
criterion over the SAT. Also, Behavior (attendance) incrementally predicted GPA and course performance, and it mediated the relationship between Conscientiousness and both academic criteria. Personality measures are predictors of academic outcomes which posted the possibility of their usefulness in admissions and student development.

The study of Bjurberg (2014) entitled "Academic achievement and personality traits: An empirical and neurobiological investigation" explored how personality traits are connected to academic achievement. Personality traits, such as Conscientiousness, Order, and Self-Discipline, and the character strengths Persistence, Love of Learning, Perspective, and OpenMindedness, are positively correlated to academic achievement.

As found by Chamorro-Premuzic \& Furnham (2008), academic performance (AP) is correlated with ability, achieving and deep learning approaches, Openness, and Conscientiousness. Together, these variables explained 40 percent of the variance in academic performance. Path analyses indicated that personality and learning approaches mediated the effects of ability on academic achievement.

This study sought to discover if the personality traits and academic performance of the senior high school students of Accountancy, Business and Management Strand of the University of Bohol is related to each other.

\section{METHODOLOGY}

This study utilized a quantitative, descriptive, normative survey and used a modified questionnaire.

This study was conducted at the University of Bohol located at Dr. Cecilio Putong Street, Tagbilaran City, Bohol. The respondents of this study were the 126 Grade 12 students and 115 Grade 11 students of University of Bohol - Senior High School taking up Accountancy, Business, and Management strand. Overall, there are 241 ABM strand students of UB-SHS. A complete enumeration of the students took part in this study.

The study utilized a modified questionnaire based on the Big Five Personality Test by J.M Digman and Lewis Goldberg. The questionnaire consisted of (2) two parts, namely: demographic profile of the respondents and the questions on personality traits with 50 items. The intended respondents were to specify their answers according to the prescribed scales as follows: 


\begin{tabular}{llll}
\hline Scale & Descriptive Value & Interpretation & Meaning/Description \\
\hline 4 & Always & Very High & $\begin{array}{l}\text { The statement specifies a very high } \\
\text { level of personality traits. }\end{array}$ \\
3 & Often & High & $\begin{array}{l}\text { The statement specifies a high level of } \\
\text { personality traits. }\end{array}$ \\
2 & Sometimes & Low & $\begin{array}{l}\text { The statement specifies a low level of } \\
\text { personality traits. }\end{array}$ \\
1 & Never & Very Low & $\begin{array}{l}\text { The statement specifies a very low } \\
\text { level of personality traits. }\end{array}$ \\
\hline
\end{tabular}

A questionnaire was used in attaining the goal and purpose of the study. Before the final distribution of the questionnaire, 15 students of the Science, Technology, Engineering, and Mathematics (STEM) Strand served as initial respondents for pilot testing. The researchers personally distributed the questionnaire to the respondents during the time allotted for the vacant period to avoid class distractions. The researchers gave clear explanations of the purpose and importance of the study. The respondents were given enough time to answer the questions. After data gathering, the researchers validated, analyzed, and interpreted the questionnaire through the gathered data.

The researchers briefed the respondents with their rights from the start until the finish of this study. The researchers further upheld the complete anonymity of the respondents according to the Data Privacy Law of 2012. The adviser and the research teacher secured consent for the retrieval of the respondents' grades from the registrar. Signatures of the respondents served as the confirmation of their personal volition to answer the questionnaires.

The researchers used the following statistic tools: percentage, Pearson $r$, and T-test. 


\section{RESULTS AND DISCUSSION}

Table 1. Summary of the Personality Traits

\begin{tabular}{|c|c|c|c|c|c|}
\hline \multicolumn{2}{|c|}{ Personality Trait } & \multicolumn{2}{|c|}{$\begin{array}{l}\text { Composite } \\
\text { Mean }\end{array}$} & \multirow{2}{*}{$\begin{array}{c}\text { DV } \\
\text { High }\end{array}$} & \multirow{2}{*}{$\begin{array}{c}\text { Rank } \\
4\end{array}$} \\
\hline 1 & \multicolumn{2}{|l|}{ Openness } & 2.99 & & \\
\hline 2 & \multicolumn{2}{|l|}{ Conscientiousness } & 3.35 & Very High & 1 \\
\hline 3 & \multicolumn{2}{|l|}{ Extraversion } & .20 & High & 2 \\
\hline 4 & \multicolumn{2}{|l|}{ Neuroticism } & .93 & High & 5 \\
\hline 5 & Agreeableness & \multicolumn{2}{|c|}{3.10} & High & 3 \\
\hline Scale & Descriptive Value & Legend & Interpretation & \multicolumn{2}{|c|}{ Meaning/Description } \\
\hline 4 & Always & $3.35-4.00$ & Very High & \multicolumn{2}{|c|}{$\begin{array}{l}\text { The statement specifies a } \\
\text { very high level of personality } \\
\text { traits. }\end{array}$} \\
\hline 3 & Often & $2.50-3.24$ & High & \multicolumn{2}{|c|}{$\begin{array}{l}\text { The statement specifies } \\
\text { a high level of personality } \\
\text { traits. }\end{array}$} \\
\hline 2 & Sometimes & $1.75-2.49$ & Low & \multicolumn{2}{|c|}{$\begin{array}{l}\text { The statement specifies a } \\
\text { low level of personality traits. }\end{array}$} \\
\hline 1 & Never & $1.00-1.74$ & Very Low & \multicolumn{2}{|c|}{$\begin{array}{l}\text { The statement specifies a } \\
\text { very low level of personality } \\
\text { traits. }\end{array}$} \\
\hline
\end{tabular}

The personality trait that ranked number one was the item on Conscientiousness with a weighted mean of 3.35 that reflected a very high level of personality trait. A person with Conscientiousness includes high ranges of thoughtfulness, properly impulse control, and goal-directed behaviors. This finding agrees with the study of Busato, Prins, Elshout, \& Hamaker, (1998) entitled "The relation between learning styles, the Big Five personality traits and achievement motivation in higher education." It states that Conscientiousness is used to be associated positively with the meaning, reproduction, and utility directed mastering style, and negatively with the undirected getting-to-know style. Meanwhile, the personality trait that ranked number 5 is neuroticism with a weighted mean of 2.93, interpreted as a high level of the personality trait. Neuroticism, according to the Big Five Dimensions of Personality theory is a trait characterized by 
sadness, moodiness, and emotional stability. It states that the individuals who are high in this trait tend to experience temper swings, anxiety, irritability, and sadness. In the same study by Busato et. al (1998), neuroticism was positively correlated with the undirected getting to know fashion and negatively with the means and reproduction directed gaining knowledge of style.

\section{Table 2. Academic Performance of the Students}

$(N=224)$

\begin{tabular}{llllll}
\hline \multicolumn{1}{c}{$\begin{array}{c}\text { Level of } \\
\text { Performance }\end{array}$} & Rating & Remarks & Frequency & Percentage & Rank \\
\hline Outstanding & $90-100$ & Passed & 160 & 71.43 & 1 \\
Very Satisfactory & $85-89$ & Passed & 56 & 25 & 2 \\
Satisfactory & $80-84$ & Passed & 6 & 2.70 & 3 \\
Fairly Satisfactory & $75-79$ & Passed & 2 & 0.90 & 4 \\
$\begin{array}{l}\text { Did Not Meet } \\
\text { Expectations }\end{array}$ & Below 75 & Failed & 0 & 0 & 5 \\
Total & & & 224 & 100 & \\
Mean=92.29 & & & & \\
Level of Performance= Outstanding & & & \\
\hline
\end{tabular}

The mean of the academic performance of the students was 92.29 , and its level of performance was outstanding. Out of 224 ABM strand students, $160(71.43 \%)$ of them had an outstanding rating, $56(25 \%)$ of them had very satisfactory, six $(2.70 \%)$ of them had a satisfactory rating, and two $(0.90 \%)$ of them had a fairly satisfactory rating and was the lowest in rank.

\section{CONCLUSIONS}

The ABM strand students of University of Bohol - Senior High School obtained high-level in the four dimensions of big five of personality traits theory. Specifically, they rated high on Openness, Extraversion, Neuroticism, and Agreeableness. Meanwhile, they rated very high on Conscientiousness. The respondents in their overall academic performance attained an outstanding rating. There was no difference between personality traits and sex, also with academic performance and sex. The researchers finally concluded that there was no significant relationship between personality traits and academic performance of the ABM strand students of University of Bohol Senior High 
School. Concerning the ABM strand students of University of Bohol Senior High School, the personality traits of the students did not affect their academic performance.

\section{REFERENCES CITED}

Ackerman.(2017). Big Five Personality Traits \& The 5-Factor Model Explained [+PDF]. Retrieved from https://bit.ly/2fSf9no, (accessed last 8 May 2018).

Barrick, M., Mount, M., \& Judge, T. (2008). Personality and Performance at the Beginning of the New Millennium: What Do We Know and Where Do We Go Next?. Retrieved from https://bit.ly/2FUxts6, (accessed last 8 May 2018).

Bjurberg, H. (2014). Academic achievement and personality traits: An empirical and neurobiological investigation. Retrieved from https://bit. ly/2BmnFV0, (accessed last 5 February 2018).

Boyle, G. (2010). Current research in personality traits and individual differences. Retrieved from https://bit.ly/2UBbuuC, (accessed last 5 February 2018).

Busato, V. V., Prins, F. J., Elshout, J. J., \& Hamaker, C. (1998). The relation between learning styles, the Big Five personality traits and achievement motivation in higher education. Personality and individual differences, 26(1), 129-140. Retrieved from https://bit.ly/2JNyTZe, (accessed last 5 February 2018).

Chamorro-Premuzic, T., \& Furnham, A. (2008). Personality, intelligence and approaches to learning as predictors of academic performance. Personality and individual differences, 44(7), 1596-1603. Retrieved from https://bit.ly/2mj1daq, (accessed last 5 February 2018).

Conard, M. A. (2006). Aptitude is not enough: How personality and behavior predict academic performance. Journal of Research in Personality, 40(3), 339-346. Retrieved from https://bit.ly/2mrSgvP, (accessed last 5 February 2018). 
Diener, E. \& Lucas, R. E. (2018). Personality traits Retrieved from https://bit. ly/2DaQbc1, (accessed last 5 February 2018).

Hogan, R. (1998), What is Personality Psychology? Psychological Inquiry - Commentaries. p1-5 Retrieved from https://bit.ly/2kSYzYA, (accessed last 8 May 2018).

Kumari, B. (2014). The correlation of Personality Traits and Academic Performance: A review of literature. Retrieved from https://bit. ly4RghdPyu, (accessed last 5 February 2018).

Lumen Candela. (2015). Education and the Global Perspective. Retrieved from https://bit.ly/2BoHLhc, (accessed last 7 February 2018).

Ongore, O. (2014). A Study of Relationship between Personality Traits and Job Engagement. Retrieved from https://bit.ly/2RGZfLj, (accessed last 5 February 2018).

Ward, A., Stroke, W.H., \& Ward, M. (1996). Achievement and Ability Tests - Definition of the Domain Educational Measurement. Retrieved from https://bit.ly/6rYthghDp, (accessed last 5 February 2018). 